\title{
Oncogene amplification pattern in adenoid cystic carcinoma of the salivary glands
}

\author{
GUADALUPE SEQUEIROS-SANTIAGO ${ }^{1}$, DARIO GARCÍA-CARRACEDO ${ }^{2}$, MANUEL F. FRESNO $^{3}$, \\ CARLOS SUAREZ ${ }^{1,2}$, JUAN P. RODRIGO ${ }^{1,2}$ and M. VICTORIA GONZALEZ ${ }^{2}$ \\ ${ }^{1}$ Servicio de Otorrinolaringología, Hospital Universitario Central de Asturias (HUCA); ${ }^{2}$ Instituto Universitario \\ de Oncología del Principado de Asturias (IUOPA), Universidad de Oviedo; ${ }^{3}$ Servicio Anatomía Patológica, \\ Hospital Universitario Central de Asturias (HUCA), Oviedo, Asturias, Spain
}

Received July 26, 2008; Accepted November 4, 2008

DOI: 10.3892/or_00000344

\begin{abstract}
The aim of the present study was the search of molecular alterations (oncogene amplification or protein overexpression) that could have an impact on the outcome of ACC patients. For this purpose, paraffin-embedded tissue samples of primary ACC of 24 patients were collected. Oncogenic amplification status of six targets previously described to be involved in human carcinogenesis (ERBB1, KIT, PIK3CA, CCND1, MYC and MDM2) were studied by a PCR-based semiquantitative approach. C-Kit, cyclin D1 and EGFR protein levels were immunohistochemically assessed. ERBB 1, CCND1 and PIK3CA were frequent targets of oncogene amplification $(67,46$ and $38 \%$, respectively). C-Kit and cyclin D1 were overexpressed in 57 and $82 \%$, respectively. CCND1 amplification was associated with advanced tumour stage and $E R B B 1$ amplification to distant metastasis. ERBB1/CCND1/PIK3CA coamplification was the most consistently observed pattern $(29 \%)$. The cases with this amplification pattern presented a reduced survival. This study points to the importance of $E R B B 1, C C N D 1$ and $P I K 3 C A$ oncogenic amplification status in ACC carcinogenesis.
\end{abstract}

\section{Introduction}

Adenoid cystic carcinoma (ACC) is one of the most common malignant tumours of the major and minor salivary glands and represents $1 \%$ of the tumours of the head and neck region. It was first described by Billroth in 1856 with the term 'cylindrome' from its cylindric histological appearance (1). ACC consists of epithelial cells that form ducts containing

Correspondence to: Dr Maria Victoria Gonzalez, Instituto Universitario de Oncología del Principado de Asturias (IUOPA). Residencia Covadonga $1^{\text {a }}$ planta CENTRO, c/Celestino Villamil, s/n 33006 Oviedo, Asturias, Spain

E-mail: gonzalezvictoria@uniovi.es

Key words: adenoid cystic carcinoma, ERBB1, CCND1, PIK3CA, immunohistochemistry mucopolisaccarides and myoepithelial cells that secrete basal membrane components. ACC shows various histological patterns such as cribiform, tubular, and solid that can coexist within the same tumour, with the predominant form allowing for some degree of outcome prediction. It is generally regarded that tubular or cribiform pattern dominant subtypes have much better prognosis than those with predominantly solid patterns (2).

Although ACC tends to grow slowly, this neoplasm has a poor prognosis, due to its insidious invasion into adjacent tissue and hematogenous spread to distant organs (lung, bone and liver) $(3,4)$. It is also characterized by extensive perineural invasion (5). Curative surgery, the mainstay of treatment for local disease, has failed to reduce mortality over the past decades. The 5-year disease-free survival rate reaches $90 \%$ but dramatically drops to $40 \%$ after 15 years (6).

Lymph node involvement, advanced tumour stage, perineural invasion and solid subtype are among the clinicopathological parameters that have been proposed to be useful predictors of the ACC clinical course (6). However, accurate prediction is often difficult and there is a need to explore additional parameters with prognostic value.

With respect to chromosomal alterations in ACC, gains $(22 q 13)(7,8)$ were detected far more frequently than losses (12q12-q13, 6q, 17p) (9). Immunohistochemical detection of p53 has been shown to be a consistent marker of aggressiveness in ACC, being highly expressed in the solid pattern (10). Recent oligonucleotide microarray analyses revealed a unique expression profile for ACC. Genes that are highly overexpressed in this tumour include several transcription factors, such as SOX4 and AP- $2 \gamma$, and members of the Wnt/B-catenin pathway (11).

EGFR, C-Kit (cell surface protein receptors), p110 $\alpha$ (component of the Akt signalling pathway), cyclin D1 (cell cycle regulatory protein), MYC (transcription factor) and MDM2 (p53 activity regulatory protein) are all encoded by oncogenes [ERBBI (7p12-14), KIT (4q11-12), PIK3CA (3q26.3), CCND1 (11q13), MYC (8p24) and MDM2 (12q13-14), respectively] that have been shown to be involved in human carcinogenesis. In a search for molecular alterations that could help in the outcome prediction of ACC patients, we set out to study the gene and protein status of these targets. 


\section{Material and methods}

Adenoid cystic carcinoma tissue specimens. Tumour tissue from 24 patients with ACC of minor and major salivary glands who consecutively underwent resection of their tumours at the Hospital Universitario Central de Asturias (HUCA) between 1984 and 2004 were obtained from archival, paraffinembedded blocks from that hospital in order to perform a retrospective analysis, with institutional review board approval for guidelines on ethical procedures. All persons gave their informed consent prior to their inclusion in the study. The diagnosis was confirmed for each lesion by a pathologist. Representative sections from tissue were used for DNA extraction and immunohistochemical analysis.

Tumour distribution according to the site of origin was: $70 \%$ (17 cases) arose at minor salivary glands, while the rest corresponded to major salivary glands. The most frequent tumour primary site was the maxilary sinus (5 cases, $21 \%$ ), followed by the parotid ( 4 cases, $16 \%$ ), the palate and the submaxilar gland (3 cases each, 12\%), the ethmoid, nasal fossa and the sublingual gland (2 cases each, $8 \%$ ) and, finally, one case in the nasopharynx, one in the pterygoid fossa and one more in the infratemporal fossa.

The characteristics of the studied patients (age, sex and toxic habits) and the clinicopathological features of their tumours [pT-category, perineural invasion, histopathologic subtype, resection margins and tumour-node-metastasis (TNM) staging system of the International Union Against Cancer, 6th edition] are shown in Table I.

None of the patients was thought to have distant metastasis at the time of diagnosis. The follow-up period ranged from 3 to 23 years. Local recurrence (6 cases) and distant metastasis ( 7 cases) incidence during this time were recorded.

Complete macroscopic resection was afforded for all cases. This was the only treatment applied to 4 patients; additionally, 17 patients received radiotherapy and 3 cases chemotherapy, whose tumours were locally advanced or showed positive resection margins.

DNA extraction. The microdissected samples (five $4-\mu \mathrm{m}$ thick slides) were processed as previously described (12). Briefly, samples were placed in xylene $(3 \times 30 \mathrm{~min})$ to remove the paraffin, pelleted in ethanol, dried and incubated in lysis buffer (50 mM Tris pH 8.5, $10 \mathrm{mM}$ EDTA, 0.5\% Tween-20, $1 \mathrm{mg} / \mathrm{ml}$ Proteinase $\mathrm{K}$ ) at $55^{\circ} \mathrm{C}$ overnight. Digested tissue was subjected to phenol-cloroform extraction and ethanol precipitation. Normal control DNA was isolated from paraffinembedded tissue of mucosa obtained from non-oncologic patients surgically treated of tonsillectomy.

Gene amplification analysis. Multiplex PCR allowed a semiquantitative assessment of ERBB1, KIT, PIK3CA, MDM2, $C C N D 1$ and $M Y C$ oncogene amplification. This approach has yielded reliable results when compared to quantitative PCR in a previous work at our laboratory (12). Briefly, oligonucleotides were designed for the simultaneous amplification of a fragment of the target gene and a segment of the corresponding single copy gene taken as control (Table II). PCR reactions were performed in a final volume of $20 \mu 1$ containing $200 \mathrm{mM}$ deoxynucleotide triphosphates, $2.5 \mathrm{mM}$
Table I. Clinicopathologic features of the ACC patients and their primary tumours $(n=24)$.

\begin{tabular}{|c|c|}
\hline Clinicopathological feature & No. of cases $(\%)$ \\
\hline Mean age (years) & 54 (range 14-79) \\
\hline \multicolumn{2}{|l|}{ Sex } \\
\hline Female & $16(66.7)$ \\
\hline Male & $8(33.3)$ \\
\hline \multicolumn{2}{|l|}{ pT-category } \\
\hline 1 & $1(4.2)$ \\
\hline 2 & $6(25)$ \\
\hline 3 & $6(25)$ \\
\hline 4 & $11(45.8)$ \\
\hline \multicolumn{2}{|l|}{ Perineural invasion } \\
\hline No & $7(29.17)$ \\
\hline Yes & $17(70.83)$ \\
\hline \multicolumn{2}{|l|}{ Histological subtype } \\
\hline Tubular & $3(12.5)$ \\
\hline Cribiform & $18(75)$ \\
\hline Solid & $3(12.5)$ \\
\hline \multicolumn{2}{|l|}{ Resection margins } \\
\hline Free & $7(29.17)$ \\
\hline Affected & $17(70.84)$ \\
\hline \multicolumn{2}{|l|}{ Tumour stage } \\
\hline $\mathrm{I}$ & $1(4.17)$ \\
\hline II & $6(25)$ \\
\hline III & $5(20.83)$ \\
\hline IV & $12(50)$ \\
\hline \multicolumn{2}{|l|}{ Toxic habits } \\
\hline None & $15(62.5)$ \\
\hline Tobacco & $6(25)$ \\
\hline Tobacco and alcohol & $3(12.5)$ \\
\hline
\end{tabular}

$\mathrm{MgCl}_{2}, 200 \mathrm{ng}$ DNA, $0.5 \mathrm{mM}$ each oligonucleotide and $0.5 \mathrm{U}$ AmpliTaq Gold (Applied Biosystems, Foster City, CA). The reaction conditions were: a $10 \mathrm{~min}$ step at $95^{\circ} \mathrm{C}$ (enzyme activation) followed by 30 cycles of $95^{\circ} \mathrm{C}$ for $1 \mathrm{~min}, \mathrm{~T}_{\mathrm{m}}$ for 1 $\min , 72^{\circ} \mathrm{C}$ for $1 \mathrm{~min}$ and a final $10 \mathrm{~min}$ step at $72^{\circ} \mathrm{C}$. PCR products were separated on $2 \%$ agarose gels and visualized by ethidium bromide staining. All the reactions were carried out at least twice in independent experiments.

C-Kit, cyclin D1 and EGFR immunohistochemical analysis. Tissue sections $(4 \mu \mathrm{m})$ were subjected to hematoxylineosin staining and the pathologist verified the presence of representative ACC tissue. Then, four micrometer serial formalin-fixed paraffin-embedded sections were incubated overnight at $54-56^{\circ} \mathrm{C}$, deparaffinized in xylene and rehydrated through decreasing graded ethanol solutions. Endogenous peroxidase activity was suppressed by incubation for $10 \mathrm{~min}$ with the peroxidase block reagent ( $3 \%$ hydrogen peroxide) 
Table II. Oligonucleotide sequences of primer pairs used for oncogene amplification. ${ }^{\mathrm{a}}$

\begin{tabular}{|c|c|c|c|c|c|c|}
\hline Gene & Exon & Locus & & Sequence $5^{\prime} \rightarrow 3^{\prime}$ & bp & $\operatorname{Tm}\left({ }^{\circ} \mathrm{C}\right)$ \\
\hline ERBB1 & 28 & $7 \mathrm{p} 11.2$ & $\begin{array}{l}\text { Fwd: } \\
\text { Rvs: }\end{array}$ & $\begin{array}{l}\text { AGGTCCTCCATCCCAACAGC } \\
\text { AATGCAACTTCCCAAAATGTGC }\end{array}$ & 122 & 58 \\
\hline$\beta-A C T$ & & $7 \mathrm{p} 15-\mathrm{p} 12$ & $\begin{array}{l}\text { Fwd: } \\
\text { Rvs: }\end{array}$ & $\begin{array}{l}\text { TGCTATCCAGGCTGTGCTATCC } \\
\text { CTTCATGAGGTAGTCAGTCAGGTCC }\end{array}$ & 171 & 58 \\
\hline$K I T$ & 2 & $4 q 11-q 12$ & $\begin{array}{l}\text { Fwd: } \\
\text { Rvs: }\end{array}$ & $\begin{array}{l}\text { TTCTCAACCATCTGTGAGTCCAG } \\
\text { GTGTTGGTGGCTTCTGCCT }\end{array}$ & 204 & 60 \\
\hline$B A N K$ & & $4 q 24$ & $\begin{array}{l}\text { Fwd: } \\
\text { Rvs: }\end{array}$ & $\begin{array}{l}\text { CACAGAACCCAGCATTTCATC } \\
\text { AACTCTDCACTGCCAACCTCTAGTG }\end{array}$ & 150 & 60 \\
\hline$P I K 3 C A$ & 21 & $3 q 26.3$ & $\begin{array}{l}\text { Fwd: } \\
\text { Rvs: }\end{array}$ & $\begin{array}{l}\text { GAGAGGTTTCAGGAGATGTGT } \\
\text { GGCTAGGGTCTTTCGAATGTA }\end{array}$ & 150 & 60 \\
\hline COL7A1 & & $3 \mathrm{p} 21.1$ & $\begin{array}{l}\text { Fwd: } \\
\text { Rvs: }\end{array}$ & $\begin{array}{l}\text { GTAACAGACCTGCAAGCCAC } \\
\text { GAGAGGGCTGGAGGTACAC }\end{array}$ & 187 & 60 \\
\hline CCND1 & 1 & $11 \mathrm{q} 13$ & $\begin{array}{l}\text { Fwd: } \\
\text { Rvs: }\end{array}$ & $\begin{array}{l}\text { CGTACCCCGATGCCAACC } \\
\text { ATGGACGGCAGGACCTCC }\end{array}$ & 121 & 60 \\
\hline$T H$ & & $11 \mathrm{q} 13$ & $\begin{array}{l}\text { Fwd: } \\
\text { Rvs: }\end{array}$ & $\begin{array}{l}\text { GCCCCAGCTGCATCCTAC } \\
\text { CTTGGCAGACACCTGGGG }\end{array}$ & 188 & 60 \\
\hline$M D M 2$ & 2 & $12 \mathrm{q} 14.3-\mathrm{q} 15$ & $\begin{array}{l}\text { Fwd: } \\
\text { Rvs: }\end{array}$ & $\begin{array}{l}\text { GCTGCAGGGCCTATAGTTCTGGG } \\
\text { GGCCAATTTCTCCACATGGTCTTG }\end{array}$ & 225 & 62 \\
\hline$P F K M$ & & $12 q 13.3$ & $\begin{array}{l}\text { Fwd: } \\
\text { Rvs }\end{array}$ & $\begin{array}{l}\text { CCGAGCTGCCTACAACCTGGT } \\
\text { GTACACGCGTGCACGTACCG }\end{array}$ & 188 & 62 \\
\hline$M Y C$ & 1 & $8 q 24.12$ q24.13 & $\begin{array}{l}\text { Fwd: } \\
\text { Rvs: }\end{array}$ & $\begin{array}{l}\text { CCCGGACGACGAGACCTTCATC } \\
\text { GCGGCGCTCAGATCCTGCAG }\end{array}$ & 198 & 60 \\
\hline$t P A$ & & $8 \mathrm{p} 12$ & $\begin{array}{l}\text { Fwd: } \\
\text { Rvs: }\end{array}$ & $\begin{array}{l}\text { CAAAGGAGGGCTCTTCGCCGACATC } \\
\text { CCTGGAAGCAGTGGGCGGCAGA }\end{array}$ & 149 & 60 \\
\hline
\end{tabular}

${ }^{a}$ Assessment and control genes (in brackets): CCND1, $(T H)$; PIK3CA, (COL7A1); ERBB1, ( $\left.\beta-A C T\right) ; M D M 2,(P F K M) ; M Y C,(t P A) ; K I T$ (BANK).

(Dako). After antigen retrieval (boiling in $10 \mathrm{mM}$ citrate buffer, pH 6.4 for cyclin D1 and C-Kit, or proteinase K treatment for EGFR), sections were processed on a Dako TechMate 500 immunostainer to obtain uniform staining. Non-specific staining was blocked with ChemMate ${ }^{\mathrm{TM}}$ wash buffer 1 . Immunostaining was performed with the following specific primary antibodies: mouse monoclonal anti-cyclin D1 DSC-6 (1:20 dilution, overnight, Novocastra Laboratories Co., Ltd., Newcastle-upon-Tyne, UK), rabbit polyclonal anti-C-Kit (CD117, A4502) (1:200 dilution, 30 min, Dako, Carpinteria, CA) and mouse monoclonal anti-EGFR 2-18C9 (pharmDx$\mathrm{Ab}$ - kit EGFR PharmDx ${ }^{\mathrm{TM}}$ K 1494, DakoCytomation). The sections were then incubated with the peroxidase-labelled polymer conjugated goat anti-rabbit/mouse secondary antibody for $30 \mathrm{~min}$ at room temperature. The stained proteins were visualized using the DAB solution provided in the kit, and lightly counterstained with hematoxylin. To ascertain the specificity of the antibody immunoreactivity, negative controls were carried out by exclusion of the primary antibody. In this case, immunolabeling was completely abolished. Healthy tonsil, colon carcinoma and melanoma tissues were also included as appropriate positive controls for cyclin D1, EGFR and C-Kit, respectively.

Statistical analysis. The molecular data distributed among the different clinical groups of tumours were tested for significance employing the $\chi^{2}$, with Yates correction when appropriate. Survival curves were calculated using the KaplanMeier product limit estimate. Deaths from causes other than the index tumour or its metastases were not considered treatment 
Table III. Distribution of cases according to the number of amplified oncogenes, detailing the most frequently observed pattern.

\begin{tabular}{lcc}
\hline $\begin{array}{l}\text { No. of } \\
\text { amplified } \\
\text { oncogenes }\end{array}$ & $\begin{array}{c}\text { No. of } \\
\text { cases }\end{array}$ & $\begin{array}{c}\text { Most frequently observed } \\
\text { amplification pattern }\end{array}$ \\
\hline 0 & 4 & -- \\
1 & 8 & $E R B B 1-5 / 8(62.5 \%)$ \\
2 & 5 & $E R B B 1$ and $C C N D 1-3 / 5(60 \%)$ \\
3 & 7 & $E R B B 1, C C N D 1$ and $P I K 3 C A-7 / 7(100 \%)$ \\
\hline
\end{tabular}

failures, and these patients were censored in all analysis involving the length of survival. Differences between survival times were analyzed by the log-rank method. All statistical analysis was carried out with the help of the software package SPSS 12.0 (SPSS, Inc., Chicago, IL). All tests were two-sided. $\mathrm{p}<0.05$ values were considered statistically significant.

\section{Results}

Oncogene amplification. We employed a PCR-based semiquantitative approach to determine the relative abundance of the target oncogene present in ACC samples with respect to a reference gene. $E R B B 1$ was the most frequently amplified oncogene (67\%), followed by CCNDI (46\%) and PIK3CA (38\%). This alteration was very rarely/never detected for $M Y C$ (9\%), KIT (5\%) and MDM2 (0\%) genes. Table III shows the most frequently observed amplification pattern given a number of oncogenes amplified.

Importantly, 7/24 (29\%) of the ACC harboured ERBB1, $C C N D 1$ and PIK3CA oncogene amplification, being the most consistently observed pattern in this study.

A statistically significant correlation was found between PIK3CA and CCND1 amplification (7/9 cases showing PIK3CA amplification were also positive for CCND1 amplification, $\mathrm{p}=0.015$ ), and also between $C C N D 1$ and $E R B B 1$ amplification (in 10/11 cases harbouring CCND1 amplification, $E R B B 1$ alteration was also observed, $\mathrm{p}=0.02$ ). Representative results of the PCR analysis are shown in Fig. 1.

Immunohistochemical expression of C-Kit, cyclin DI and EGFR in ACC

C-Kit expression. A membranous expression pattern was observed for every positive case. A score was assigned as the product of two parameters: extent of immunostaning (on a 0-100 point scale, after counting cells in five random fields per sample with the help of the image tool 3.0 UTHSCSA application) and staining intensity (on a 0-3 point scale). This continuous variable was categorized into three groups: null cases, and moderate versus high expressing tumours, attending to the median value of the registered scores (60). Normal salivary gland tissue did not show C-Kit expression. Among the ACC cases, 9 (43\%), 7 (33\%) and 5 cases (24\%) displayed null, moderate or high signal for C-Kit detection, respectively. Fig. 2a shows representative results of each category.

Cyclin D1 expression. A nuclear pattern was observed in every case. For each tissue section, only epithelial cell

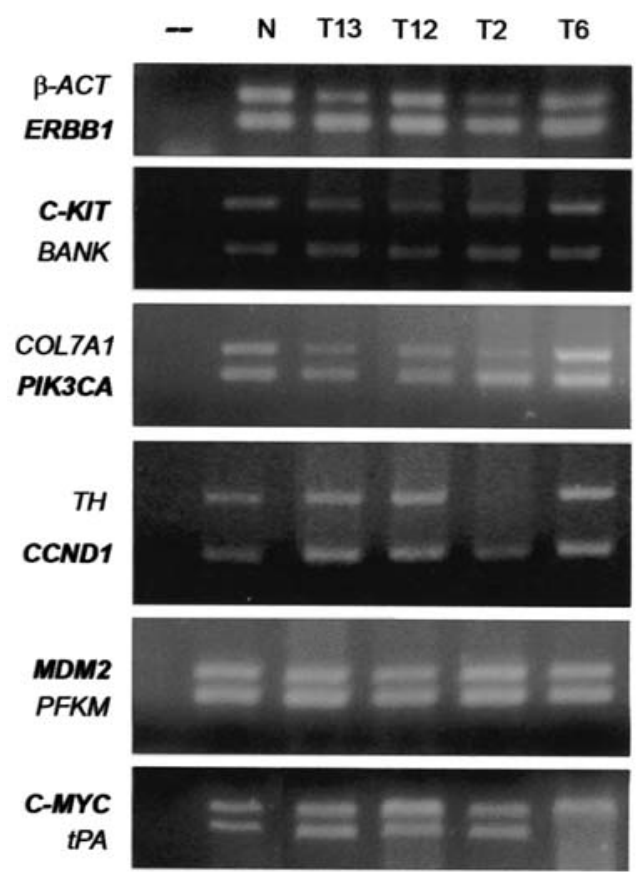

Figure 1. Representative examples of the oncogene amplification status by multiplex PCR analysis. T13, ERBB1 amplification positive tumour; T12, $M Y C$ positive; T2, shows ERBB1, PIK3CA and CCND1 coamplification; T6, KIT and MYC positive case. -, negative PCR control; N, healthy tonsil DNA control.

component showed immunoreactivity. These cells form mucopolysaccharide containing ducts, which distinguishes them from the surrounding myoepithelial cells (that resulted to be cyclin D1 negative). They secrete basal layer components. Due to the fact that $100 \%$ of the epithelial component were cyclin D1 positive, classification was established taking into account exclusively the level of the nuclear expression. Three categories were considered: low, moderate or high. Four (18\%), 7 (32\%) and $11(50 \%)$ cases were registered for each one (Fig. 2b). In contrast, normal salivary gland tissue failed to show cyclin D1 expression.

EGFR expression. None of the studied tumour samples or normal salivary gland tissues showed EGFR positive signal (Fig. 2c).

Relationships between protein expression and oncogene amplification. The only case harbouring KIT amplification showed a moderate protein expression level. For statistical purposes, the cyclin D1 protein expression variable was recoded into two categories: low vs. moderate-high. Out of 11 cases with $C C N D 1$ amplification 10 showed moderate-high cyclin D1 expression levels $(\mathrm{p}=0.08)$. However, 8 additional cases also had moderate-high cyclin D1 expression without evidence of $C C N D 1$ amplification. This would point to the existence of other mechanisms different from gene amplification accounting for cyclin D1 overexpression.

Comparison of molecular findings with clinical course. Crosstabs considering oncogenic amplification and protein expression results with respect to clinicopathological features are shown in Tables IV and V, respectively. Importantly, distant metastasis correlated with ERBBI amplification in the 
a



b

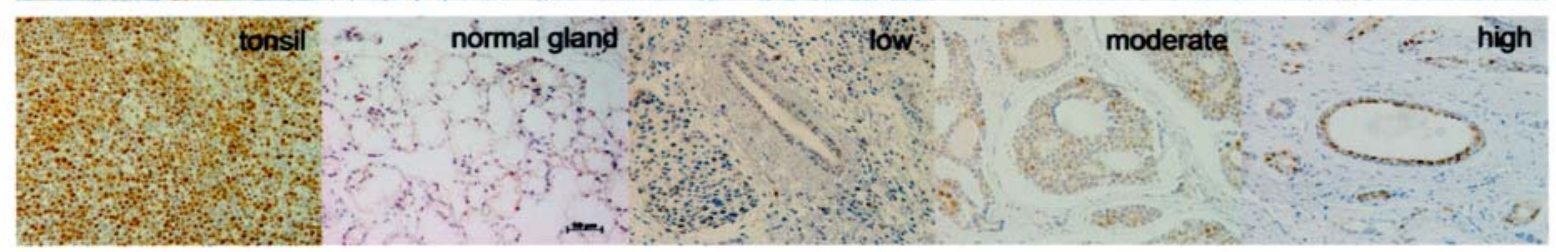

c

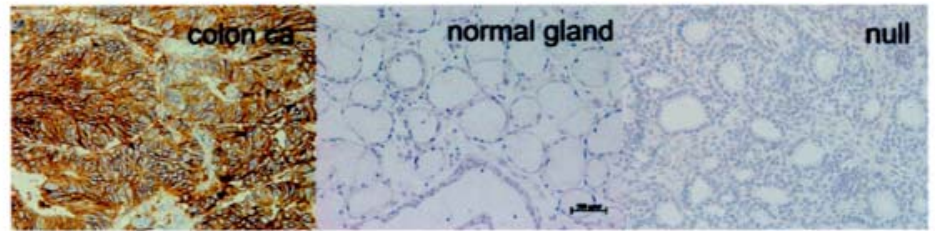

Figure 2. C-Kit (a), cyclin D1 (b) and EGFR (c) protein expression. The corresponding positive controls are indicated in each case (melanoma, tonsil and colon carcinoma, respectively). Expression patterns in normal glands were membranous for C-Kit and EGFR, and nuclear for cyclin D1. Representative images of tumours showing different expression levels are shown for each marker. Magnification, $\mathrm{x} 20$.

Table IV. Relationships between the oncogene amplification status of the most relevant targets and the tumor clinicopathological features.

\begin{tabular}{|c|c|c|c|c|c|c|c|c|c|}
\hline \multirow[b]{2}{*}{ Feature } & & \multicolumn{2}{|c|}{$E R B B 1$} & \multicolumn{2}{|c|}{ PIK $3 C A$} & \multicolumn{2}{|c|}{ CCNDI } & \multicolumn{2}{|c|}{$\begin{array}{l}\text { Most frequent } \\
\text { pattern }\end{array}$} \\
\hline & & Amp. & Total & Amp. & Total & Amp. & Total & Yes & Total \\
\hline Gland & $\begin{array}{l}\text { Minor } \\
\text { Major } \\
\text { Total } \\
\text { p }\end{array}$ & $\begin{array}{c}11 \\
5 \\
16 \\
0.751\end{array}$ & $\begin{array}{r}17 \\
7 \\
24\end{array}$ & $\begin{array}{c}7 \\
2 \\
9 \\
0.562\end{array}$ & $\begin{array}{r}17 \\
7 \\
24\end{array}$ & $\begin{array}{c}8 \\
3 \\
11 \\
0.851\end{array}$ & $\begin{array}{r}17 \\
7 \\
24\end{array}$ & $\begin{array}{c}5 \\
2 \\
7 \\
0.967\end{array}$ & $\begin{array}{r}17 \\
7 \\
24\end{array}$ \\
\hline $\mathrm{T}$ category & $\begin{array}{l}\text { T1-2 } \\
\text { T3-4 } \\
\text { Total } \\
\text { p }\end{array}$ & $\begin{array}{c}3 \\
13 \\
16 \\
0.112\end{array}$ & $\begin{array}{r}7 \\
17 \\
24\end{array}$ & $\begin{array}{c}2 \\
7 \\
9 \\
0.562\end{array}$ & $\begin{array}{r}7 \\
17 \\
24\end{array}$ & $\begin{array}{c}1 \\
10 \\
11 \\
0.047\end{array}$ & $\begin{array}{r}7 \\
17 \\
24\end{array}$ & $\begin{array}{c}1 \\
6 \\
7 \\
0.303\end{array}$ & $\begin{array}{r}7 \\
17 \\
24\end{array}$ \\
\hline $\begin{array}{l}\text { Perineural } \\
\text { invasion }\end{array}$ & $\begin{array}{l}\text { No } \\
\text { Yes } \\
\text { Total } \\
\text { p }\end{array}$ & $\begin{array}{c}3 \\
13 \\
16 \\
0.112\end{array}$ & $\begin{array}{r}7 \\
17 \\
24\end{array}$ & $\begin{array}{c}3 \\
6 \\
9 \\
0.727\end{array}$ & $\begin{array}{r}7 \\
17 \\
24\end{array}$ & $\begin{array}{c}4 \\
7 \\
11 \\
0.475\end{array}$ & $\begin{array}{r}7 \\
17 \\
24\end{array}$ & $\begin{array}{c}2 \\
5 \\
7 \\
0.9671\end{array}$ & $\begin{array}{r}7 \\
17 \\
24\end{array}$ \\
\hline $\begin{array}{l}\text { Histological } \\
\text { subtype }\end{array}$ & $\begin{array}{c}\text { Tubular } \\
\text { Cribiform } \\
\text { Solid } \\
\text { Total } \\
\text { p }\end{array}$ & $\begin{array}{c}2 \\
12 \\
2 \\
16 \\
0.619\end{array}$ & $\begin{array}{r}3 \\
18 \\
3 \\
24\end{array}$ & $\begin{array}{c}3 \\
4 \\
2 \\
9 \\
0.019\end{array}$ & $\begin{array}{r}3 \\
18 \\
3 \\
24\end{array}$ & $\begin{array}{c}2 \\
8 \\
1 \\
11 \\
0.695\end{array}$ & $\begin{array}{r}3 \\
18 \\
3 \\
24\end{array}$ & $\begin{array}{c}2 \\
4 \\
1 \\
7 \\
0.288\end{array}$ & $\begin{array}{r}3 \\
18 \\
3 \\
24\end{array}$ \\
\hline Metastasis & $\begin{array}{l}\text { No } \\
\text { Yes } \\
\text { Total } \\
\text { p }\end{array}$ & $\begin{array}{c}9 \\
7 \\
16 \\
0.026\end{array}$ & $\begin{array}{r}17 \\
7 \\
24\end{array}$ & $\begin{array}{c}6 \\
3 \\
9 \\
0.728\end{array}$ & $\begin{array}{r}17 \\
7 \\
24\end{array}$ & $\begin{array}{c}6 \\
5 \\
11 \\
0.106\end{array}$ & $\begin{array}{r}17 \\
7 \\
24\end{array}$ & $\begin{array}{c}4 \\
3 \\
7 \\
0.344\end{array}$ & $\begin{array}{r}27 \\
7 \\
24\end{array}$ \\
\hline
\end{tabular}

primary tumour ( $\mathrm{p}=0.026$ ). While $44 \%$ of the ERBB1 amplification positive cases $(7 / 16)$ developed distant metastasis, none of the negative cases suffered from it.

Regarding survival analysis, mean survival time of the whole population under study was 73.54 months (range:
19-276). Mean survival time of those patients who died of ACC was 47 months (range: 19-159). The 5-year and 15-year overall survival rate of 81 and $58 \%$, respectively.

The clinicopathological parameters associated with a poorer survival were the solid subtype, perineural invasion, 
a

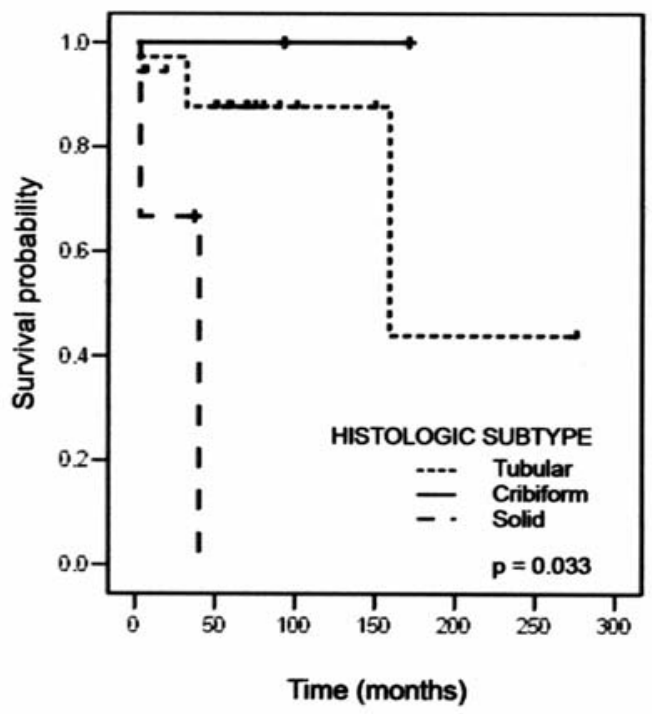

c

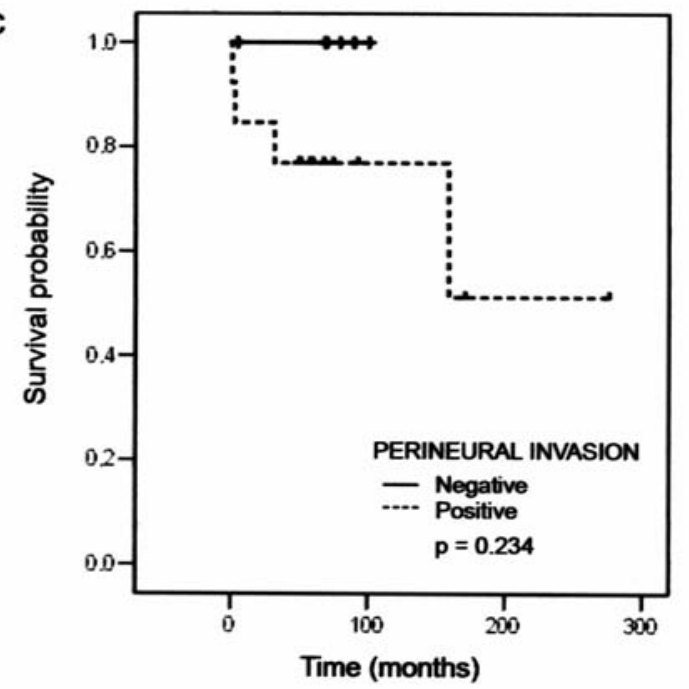

b
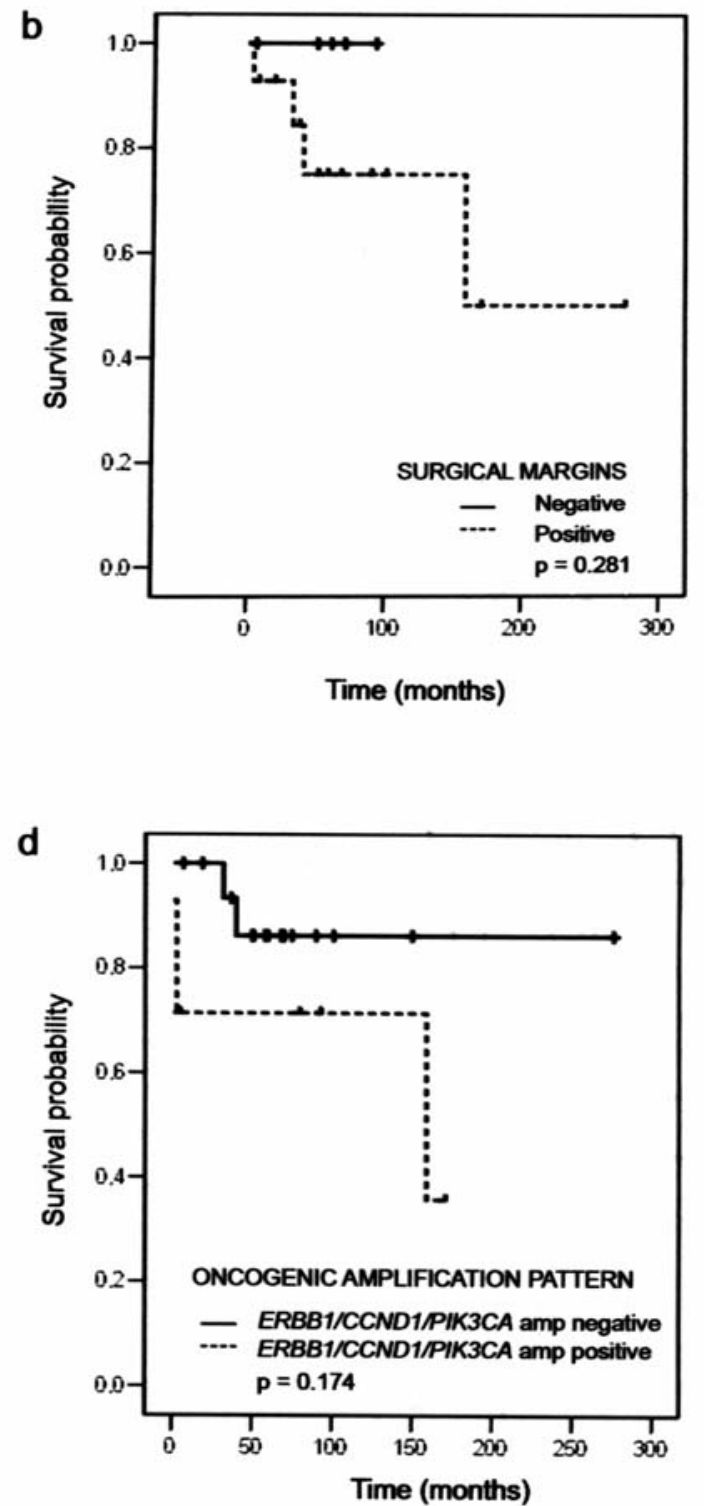

Figure 3. Survival curves corresponding to patients stratified by histologic subtype (a), surgical margins status (b), perineural invasion (c) and the presence of ERBB1, CCND1 and PIK3CA coamplification (d). Log-rank test p-values are indicated.

and surgical margin involvement. In addition, there was a tendency towards ERBB1, PIK3CA and CCND1 coamplification-bearing tumours to have a worse prognosis than the rest (mean: 118 months, S.E., 28; versus mean: 243 months, S.E., 22) (p=0.174) (Fig. 3).

\section{Discussion}

The molecular basis underlying ACC development is still poorly understood. The identification of the genetic alterations and the resulting protein expression changes responsible for ACC development are needed. In our study we chose six oncogenes, whose gain of function is related to human tumorigenesis and their involvement in ACC of the salivary glands progression was assessed. A consistent oncogenic amplification pattern (affecting ERBB1, CCNDI and PIK3CA) was observed.

Cyclin D1 overexpression is a common event in many human tumour types and was present very frequently in our
ACC series (50\% intense, $32 \%$ moderate level), irrespective of histological subtype, in line with previous reports (13-15). This is the first report describing cyclin D1 immunoreactivity restricted to the epithelial component of ACC. Epithelial cells form ducts that contain mucopolysaccarides, which differentiates them from the myoepithelial cells that secrete basal membrane components. The contribution of cyclin D1 overexpression to the cellular proliferation is a matter of debate. Some basic studies show that cellular growth is not affected by cyclin D1 inhibition (16). However, in our study, the fact that the cyclin D1 levels were higher in those cases harbouring a higher proportion of epithelial component would indirectly suggest that cyclin D1 would contribute to a higher proliferation rate, which is in agreement with the proposed role of this protein in the cellular cycle.

The precise mechanisms responsible of cyclin D1 overexpression in ACC are not fully established. Gene amplification of CCND1 might contribute (17), and has been previously described to be present in $5 \%$ of the ACC (15). 
Table V. Relationships between the protein expression levels and the tumor clinicopathological features.

\begin{tabular}{|c|c|c|c|c|c|c|c|}
\hline \multirow[b]{2}{*}{ Feature } & & \multicolumn{3}{|c|}{ C-Kit protein } & \multicolumn{3}{|c|}{ Cyclin D1 protein } \\
\hline & & Negative & Moderate & Intense & Low & Moderate & Intense \\
\hline \multirow[t]{4}{*}{ Gland } & Minor & 7 & 4 & 4 & 4 & 5 & 6 \\
\hline & Major & 2 & 3 & 1 & 0 & 2 & 5 \\
\hline & Total & 9 & 7 & 5 & 4 & 7 & 11 \\
\hline & $\mathrm{p}$ & & 0.589 & & & 0.241 & \\
\hline \multirow[t]{4}{*}{ T category } & $\mathrm{T} 1-2$ & 2 & 3 & 1 & 2 & 2 & 3 \\
\hline & T3-4 & 7 & 4 & 4 & 2 & 5 & 8 \\
\hline & Total & 9 & 7 & 5 & 4 & 7 & 11 \\
\hline & $\mathrm{p}$ & & 0.589 & & & 0.688 & \\
\hline \multirow{4}{*}{$\begin{array}{l}\text { Perineural } \\
\text { invasion }\end{array}$} & No & 3 & 3 & 0 & 2 & 1 & 3 \\
\hline & Yes & 6 & 4 & 5 & 2 & 6 & 7 \\
\hline & Total & 9 & 7 & 5 & 4 & 7 & 11 \\
\hline & $\mathrm{p}$ & & 0.247 & & & 0.289 & \\
\hline \multirow{5}{*}{$\begin{array}{l}\text { Histological } \\
\text { subtype }\end{array}$} & Tubular & 1 & 1 & 0 & 0 & 0 & 2 \\
\hline & Cribiform & 7 & 6 & 3 & 3 & 5 & 9 \\
\hline & Solid & 1 & 0 & 2 & 1 & 2 & 0 \\
\hline & Total & 9 & 7 & 5 & 4 & 7 & 11 \\
\hline & $\mathrm{p}$ & & 0.367 & & & 0.279 & \\
\hline \multirow[t]{4}{*}{ Metastasis } & No & 7 & 5 & 4 & 4 & 5 & 7 \\
\hline & Yes & 2 & 2 & 1 & 0 & 2 & 4 \\
\hline & Total & 9 & 7 & 5 & 4 & 7 & 11 \\
\hline & $\mathrm{p}$ & & 0.932 & & & 0.375 & \\
\hline
\end{tabular}

Our results point to a much higher incidence ( $46 \%$ cases). Technical approaches could account, at least in part, for this difference, being our PCR-based approach more sensitive than FISH. Importantly, CCNDI amplification correlated with a more advanced tumour stage. Although gene amplification underlies high protein expression in a proportion of cases (10/18), our results suggest the existence of other mechanisms, such as increased transcription rate, increased mRNA stability or proteasomal ubiquitin mediated protein degradation (18).

Therapeutic agents targeting epidermal growth factor receptor and its downstream signaling effectors in some head and neck cancer are now being developed. However, data regarding the role of EGFR in ACC are contradictory. Only one study describes a high proportion of EGFR positive cases (19), while most others point to a null or minimal prevalence of EGFR overexpression in ACC $(20,21)$. Our study supports these data, since no positive cases were found using a widely clinically validated antibody.

This is the first study describing ERBBI amplification in ACC. It was a very frequent finding $(67 \%)$ and it was related to metastasis incidence, suggesting its importance in the clinical practise.

The fact that no EGFR expression was detected at all, might point to other genes being the target that would contribute to ACC progression. One of these could be Grb10 that codes an adapter protein involved in human carcinogenesis (22). However, the potential value of the ERBBI amplification status in metastasis incidence prediction in ACC should not be underestimated. In breast cancer, the results of ERBB2 amplification as a prognostic factor are more consistent than protein positivity, with $E R B B 2$ amplification associated with a worse prognosis (23).

Gene amplification affected the PIK3CA gene in 38\% of the cases, being this the first description of this event in ACC. Taken into account the molecular consequences of $\mathrm{p} 110 \alpha$ activation (24), we could speculate with the possibility of an increased survival response effected by Akt activationmediated pathway in ACC cells.

PIK3CA and CCND1 coamplification was present in $21 \%$ of the cases $(7 / 24)$, a similar frequency to that found in a HNSCC in our laboratory $(28 \%, 32 / 111)$ (unpublished data). We could speculate with a synergistic effect between the amplification of these two genes in ACC progression, as has been described in HNSCC (25).

The most frequently found oncogenic amplification profile was that affecting ERBB1, CCND1 and PIK3CA (7/24 cases, $29 \%)$. Although no statistical significance was reached, probably due to the small number of cases, the patients with this amplification pattern showed a reduced survival. This observation merits further attention in the design of future works.

Contribution of MDM2, KIT and MYC oncogenic amplification to ACC seems to be low/null. Thus, according to studies carried out in salivary gland tumours of diverse origin (26) we did not find any $M D M 2$ amplification positive cases. Our series shows, for the first time, a very low prevalence of $M Y C$ 
amplification in ACC (9\%). KIT was found to be amplified in only one case. However, in line with other reports $(27,28)$, $\mathrm{C}-\mathrm{Kit}$ protein overexpression was a very frequent event (57\%). Thus, other still undetermined mechanisms must account for the protein overexpression.

The ACC series considered herein show the expected behaviour regarding overall survival (5-year rate, $85 \%$ and 15 -year rate, $58 \%$ ), as well as the known negative impact of the solid histological subtype, involvement of the surgical margins and the presence of perineural invasion in survival. These data account for the representative character of the population under study. Accumulation of a large series of ACC is a difficult task and this limitation is common to many studies reported in the literature. We have collected ACC surgically treated in a reference hospital in a 20-year interval. This illustrates the low incidence of this type of tumour and the difficulties associated with its study.

In summary, this study shows an oncogenic amplification profile that predominates in ACC (ERBB1, PIK3CA and $C C N D 1)$. On the contrary, MDM2, MYC and KIT do not seem to be affected during ACC development. ERBBI amplification might be a useful marker of poor prognosis.

\section{Acknowledgements}

This study was supported by grant from Programa Ramón y Cajal (MVG) (Ministerio de Educación y Ciencia, Spain) and Obra Social CajAstur (DGC). The Instituto Universitario de Oncología is supported by Obra Social Cajastur.

\section{References}

1. Billroth T: Die Cylindergeschwalst. Untersuchungen ueber die Entwicklung der Blutgefefasse. G. Reimer, Berlin, 1856.

2. Szanto PA, Luna MA, Tortoledo ME and White RA: Histologic grading of adenoid cystic carcinoma of the salivary glands. Cancer 54: 1062-1069, 1984.

3. Kim KH, Sung MW, Chung PS, Rhee CS, Park CI and Kim WH: Adenoid cystic carcinoma of the head and neck. Arch Otolaryngol Head Neck Surg 120: 721-726, 1994.

4. Wiseman SM, Popat SR, Rigual NR, Hicks WL Jr, Orner JB, Wein RO, McGary CT and Loree TR: Adenoid cystic carcinoma of the paranasal sinuses or nasal cavity: a 40-year review of 35 cases. Ear Nose Throat J 81: 510-517, 2002.

5. Bradley PJ: Adenoid cystic carcinoma of the head and neck: a review. Curr Opin Otolaryngol Head Neck Surg 12: 127-132, 2004.

6. Fordice J, Kershaw C, El-Naggar A and Goepfert H: Adenoid cystic carcinoma of the head and neck: predictors of morbidity and mortality. Arch Otolaryngol Head Neck Surg 125: 149-152, 1999.

7. Freier K, Flechtenmacher C, Walch A, Ohl S, Devens F, Burke B, Hassfeld S, Lichter P, Joos S and Hofele C: Copy number gains on $22 \mathrm{q} 13$ in adenoid cystic carcinoma of the salivary gland revealed by comparative genomic hybridization and tissue microarray analysis. Cancer Genet Cytogenet 159: 89-95, 2005.

8. Vekony H, Ylstra B, Wilting SM, Meijer GA, van de Wiel MA, Leemans CR, van der Waal I and Bloemena E: DNA copy number gains at loci of growth factors and their receptors in salivary gland adenoid cystic carcinoma. Clin Cancer Res 13: 3133-3139, 2007

9. Jin C, Martins C, Jin Y, Wiegant J, Wennerberg J, Dictor M, Gisselsson D, Strombeck B, Fonseca I, Mitelman F, Tanke HJ, Hoglund $\mathrm{M}$ and Mertens F: Characterization of chromosome aberrations in salivary gland tumors by FISH, including multicolor COBRA-FISH. Genes Chromosomes Cancer 30: 161-167, 2001.
10. Yamamoto Y, Wistuba, II, Kishimoto Y, Virmani AK, Vuitch F, Albores-Saavedra J and Gazdar AF: DNA analysis at p53 locus in adenoid cystic carcinoma: comparison of molecular study and p53 immunostaining. Pathol Int 48: 273-280, 1998.

11. Huang D, Chen W, He R, Yu F, Zhang Z and Qiu W: Different cDNA microarray patterns of gene expression reflecting changes during metastatic progression in adenoid cystic carcinoma. World J Surg Oncol 1: 28, 2003.

12. Pedrero JM, Carracedo DG, Pinto CM, Zapatero AH, Rodrigo JP, Nieto CS and Gonzalez MV: Frequent genetic and biochemical alterations of the PI 3-K/AKT/PTEN pathway in head and neck squamous cell carcinoma. Int J Cancer 114: 242-248, 2005.

13. Daa T, Kaku N, Kashima K, Nakayama I and Yokoyama S: Expression of beta-catenin, E-cadherin and cyclin D1 in adenoid cystic carcinoma of the salivary gland. J Exp Clin Cancer Res 24: 83-87, 2005.

14. Zhou CX and Gao Y: Aberrant expression of beta-catenin, Pin1 and cylin D1 in salivary adenoid cystic carcinoma: relation to tumor proliferation and metastasis. Oncol Rep 16: 505-511, 2006.

15. Greer RO Jr, Said S, Shroyer KR, Marileila VG and Weed SA: Overexpression of cyclin D1 and cortactin is primarily independent of gene amplification in salivary gland adenoid cystic carcinoma. Oral Oncol 43: 735-741, 2007.

16. Yasumatsu R, Kuratomi Y, Nakashima T, Masuda M and Yamamoto T: Cyclin D1 expression does not effect cell proliferation in adenoid cystic carcinoma of the salivary gland. Eur Arch Otorhinolaryngol 261: 526-530, 2004.

17. Donnellan R and Chetty R: Cyclin D1 and human neoplasia. Mol Pathol 51: 1-7, 1998.

18. Guo Y, Yang K, Harwalkar J, Nye JM, Mason DR, Garrett MD, Hitomi M and Stacey DW: Phosphorylation of cyclin D1 at Thr 286 during $\mathrm{S}$ phase leads to its proteasomal degradation and allows efficient DNA synthesis. Oncogene 24: 2599-2612, 2005.

19. Vered M, Braunstein E and Buchner A: Immunohistochemical study of epidermal growth factor receptor in adenoid cystic carcinoma of salivary gland origin. Head Neck 24: 632-636, 2002.

20. Shintani S, Funayama T, Yoshihama Y, Alcalde RE, Otsuki K, Terakado $\mathrm{N}$ and Matsumura T: Expression of c-erbB family gene products in adenoid cystic carcinoma of salivary glands: an immunohistochemical study. Anticancer Res 15: 2623-2626, 1995.

21. Kusafuka K: Expressions of oncogene products in adenoid cystic carcinomas of salivary glands: immunohistochemical study. Kokubyo Gakkai Zasshi 58: 696-717, 1991.

22. Okino K, Konishi H, Doi D, Yoneyama K, Ota Y, Jin E, Kawanami $\mathrm{O}$ and Takeshita T: Up-regulation of growth factor receptor-bound protein 10 in cervical squamous cell carcinoma. Oncol Rep 13: 1069-1074, 2005

23. Andrulis IL, Bull SB, Blackstein ME, Sutherland D, Mak C, Sidlofsky S, Pritzker KP, Hartwick RW, Hanna W, Lickley L, Wilkinson R, Qizilbash A, Ambus U, Lipa M, Weizel H, Katz A, Baida M, Mariz S, Stoik G, Dacamara P, Strongitharm D, Geddie W and McCready D: neu/erbB-2 amplification identifies a poor-prognosis group of women with node-negative breast cancer. Toronto Breast Cancer Study Group. J Clin Oncol 16: 1340-1349, 1998.

24. Manning BD and Cantley LC: AKT/PKB signaling: navigating downstream. Cell 129: 1261-1274, 2007.

25. Jin Y, Jin C, Wennerberg J, Hoglund M and Mertens F: Cyclin D1 amplification in chromosomal band 11q13 is associated with overrepresentation of 3q21-q29 in head and neck carcinomas. Int J Cancer 98: 475-479, 2002.

26. Schlott T, Nagel H, Laskawi R, Eiffert $H$ and Droese M: Genetic analysis of the human oncoprotein MDM2 in benign and malignant tumors of the salivary gland. Pathobiology 69: 67-76, 2001

27. Andreadis D, Epivatianos A, Poulopoulos A, Nomikos A, Papazoglou G, Antoniades D and Barbatis C: Detection of C-KIT (CD117) molecule in benign and malignant salivary gland tumours. Oral Oncol 42: 57-65, 2006.

28. Mino M, Pilch BZ and Faquin WC: Expression of KIT (CD117) in neoplasms of the head and neck: an ancillary marker for adenoid cystic carcinoma. Mod Pathol 16: 1224-1231, 2003. 